\title{
Upaya Meningkatkan Hasil Belajar Matematika Melalui Metode Bermain Anak Tangga
}

\author{
Wahyu Rokhati \\ UPK Jatilawang Banyumas \\ Jl. Pramuka, Tunjung Wetan, Tunjung, Kec. Jatilawang, Kabupaten Banyumas, Jawa \\ Tengah \\ Email: bdmartono7@gmail.com
}

\begin{abstract}
ABSTRAK
Latar belakang penelitian ini dilakukan karena rendahnya keaktifan dan hasil belajar siswa kelas III tentang pengukuran satuan panjang memotivasi keaktifan dan hasil belajar matematika siswa pada Kompetensi Dasar Menggunakan Alat Ukur dalam Pemecahan Masalah. Penelitian ini merupakan Penelitian Tindakan Kelas dengan subyek penelitian siswa kelas III SD Negeri 1 Karanganyar dengan jumlah siswa 19 anak. Sumber data berasal dari dokumen, siswa, dan rekan sejawat. Tehnik pengumpulan data dengan tes dan non tes. Proses penelitian dilaksanakan dalam dua siklus, setiap siklus terdiri dari 2 pertemuan masing-masing pertemuan 2 jam pelajaran. Untuk mengukur kemampuan siswa dalam menguasai materi yang telah diberikan, setiap akhir siklus dilaksanakan evaluasi. Hasil yang diperoleh dari data ada peningkatan hasil belajar dilihat dari studi awal sebelum tindakan dan sesudah tindakan. Adapun data tentang hasil belajar yang diperoleh adalah sebagai berikut: nilai rata-rata kelas pada studi awal adalah 53 dengan ketuntasan belajar 21\%; nilai rata-rata siklus 1 adalah 61 dengan ketuntasan belajar 42\%; nilai rata-rata siklus II adalah 72,5 dengan ketuntasan belajar 95\%. Dapat disimpulkan bahwa penggunaan metode bermain anak tangga dapat meningkatkan keaktifan dan hasil belajar siswa, khususnya materi Pengukuran Satuan Panjang.
\end{abstract}

Kata kunci: keaktifan siswa, meningkatkan hasil belajar siswa, metode bermain anak tangga.

\begin{abstract}
The background of this research was carried out because of the low activeness and learning outcomes of students in class III about the measurement of long units motivating the activeness and student learning outcomes of mathematics in Basic Competencies Using Measuring Tools in Problem Solving. This research is a Classroom Action Research with the subjects of third grade students of SD Negeri 1 Karanganyar with a total of 19 students. Data sources come from documents, students, and peers. Data collection techniques with test and non-test. The research process was carried out in two cycles, each cycle consisting of 2 meetings each meeting 2 lesson hours. To measure the ability of students in mastering the material that has been given, each end of the cycle carried out an evaluation. The results obtained from the data there is an increase in learning outcomes seen from the initial study before the action and after the action. The data about the learning outcomes obtained are as follows: the average grade of the class in the initial study was 53 with $21 \%$ mastery learning; the average value of cycle 1 is 61 with a $42 \%$ mastery learning; the average value of the second cycle is 72.5 with 95\% mastery learning. It can be concluded that the use of the ladder playing method can increase the activeness and learning outcomes of students, especially the Long Unit Measurement material.
\end{abstract}

Keywords: student activeness, improve student learning outcomes, methods of playing rungs. 


\section{PENDAHULUAN}

Temuan di lapangan yaitu di kelas III SD Negeri 1 Karanganyar Kecamatan Jatilawang Kabupaten Banyumas tempat peneliti bertugas masih ada kesenjangan antara harapan dan kenyataan pada bidang studi matematika kompetensi dasar pengukuran satuan panjang. Ketercapaian proses pembelajan tersebut dapat diukur dengan tes hasil. Hasil tes awal menunjukan bahwa dari 19 siswa yang terdiri atas 12 anak perempuan dan 7 anak laki-laki, hanya 4 (21\%) siswa yang mendapat nilai 60 ke atas. Sisanya yaitu 15 (79\%) siswa mempunyai nilai di bawah 60. Padahal kriteria ketuntasan minimal matematika kelas III SD Negeri 1 Karanganyar adalah 60. Berdasarkan data awal faktor penyebab rendahnya prestasi belajar siswa antara lain: 1.Penyampaian materi kurang menarik karena guru hanya menggunakan metode ceramah.2.Guru terlalu cepat pada saat menjelaskan.3.Guru kurang mampu menciptakan kondisi pembelajaran yang membangkitkan motivasi belajar siswa.4.Dalam menyampaikan guru tidak menggunakan alat peraga. Berdasarkan hasil refleksi dan diskusi dengan teman sejawat, penulis berupaya melakukan perbaikan pembelajaran sebagai alternatif tindakan. Salah satu cara dengan menerapkan metode yang bervariasi dalam pembelajaran tentang pengukuran satuan panjang dengan menggunakan metode bermain anak tangga. Tujuan penelitian ini adalah meningkatkan hasil belajar siswa dengan menerapkan metode yang bervariasi dalam pembelajaran tentang satuan pengukuran panjang menggunakan metode bermain anak tangga dapat meningkatkan kualitas pembelajaran kelas III SD Negeri 1 Karanganyar

Dalam proses pembelajaran matematika, Bruner (1982) nyatakan pentingnya tekanan pada kemampuan peserta didik dalam berpikir intuintif dan analitik akan mencerdaskan peserta didik mebuat prediksi dan terampil dalam menemukan pola (pattern) dan hubungan/keterkaitan (relation) pembaruan dalam proses belajar. Sementara para ilmuwan telah menyepakati untuk menggunakan satuan pengukuran panjang yang berlaku di seluruh dunia. Satuan pengukuran panjang ini diberi nama satuan pokok panjang.Satuan panjang yang berlaku secara internasional adalah meter. Awalnya 1 meter ditetapkan sama dengan sepersepuluh juta jarak dari kutub utara ke garis khatulistiwa melalui Kota Paris. Panjang 1 meter yang sekarang kita gunakan adalah panjang jarak yang ditempuh cahaya dalam ruang hampa udara dalam waktu yang sangat cepat. 


\section{METODE PENELITIAN}

Untuk memperoleh pelaksanaan tindakan, maka perlu disusun suatu kerangka berpikir yang merupakan landasan penelitian tindakan kelas ini.Secara jelas dapat dilihat pada dilihat pada Gambar 1.

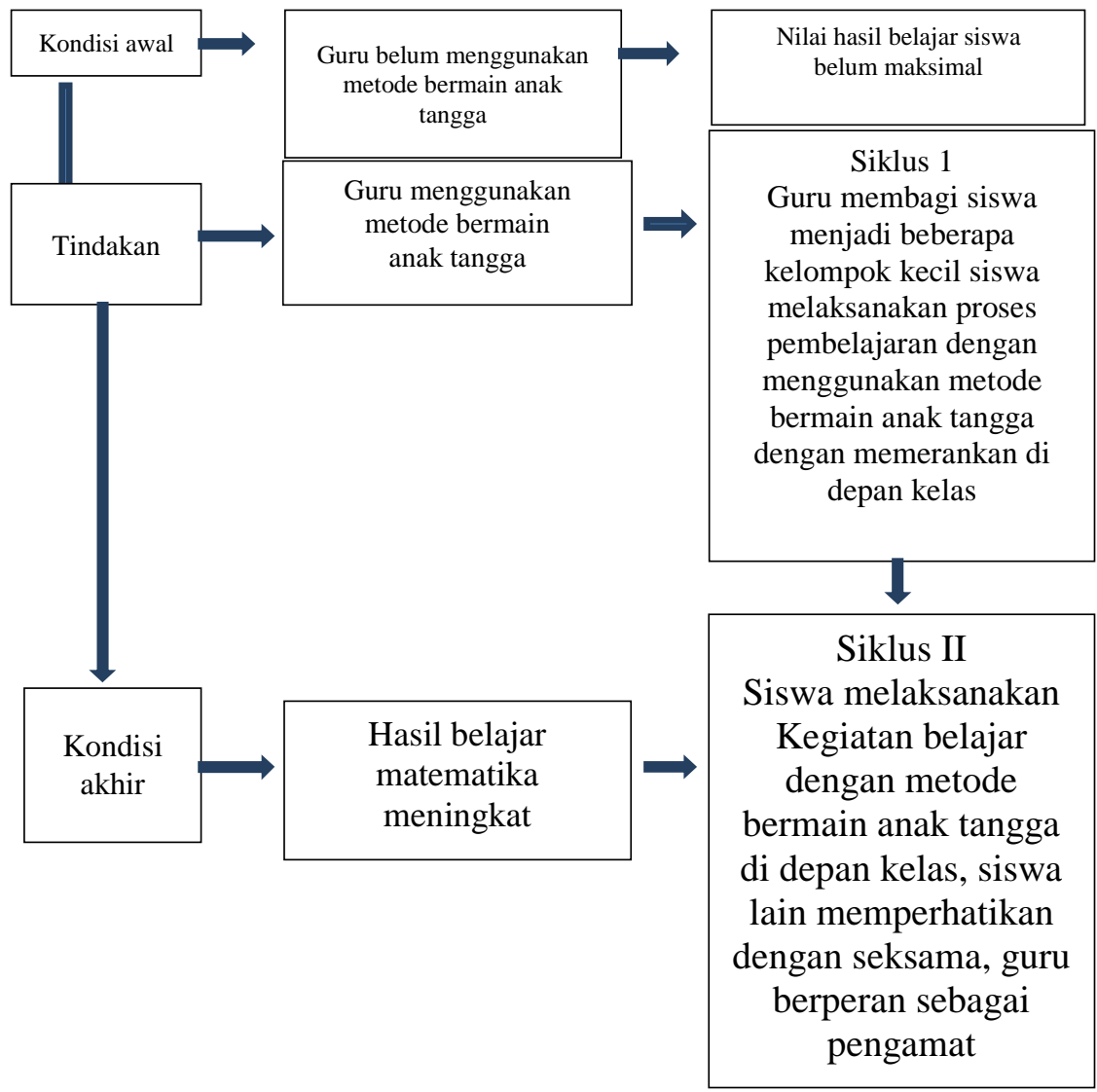

Gambar 1. Bagan Kerangka Berpikir

Pada kondisi awal guru belum menggunakan metode bermain anak tangga sehingga belajar matematika siswa masih rendah.Supaya hasil belajar meningkat, guru perlu melakukan tindakan dengan menggunakan metode bermain anak tangga. Pada pelaksanaan perbaikan siklus 1 guru menggunakan metode bermain anak tangga dalam kelompok kecil. Pada siklus 2 guru menggunakan metode bermain anak tangga, siswa melaksanakan kegiatan belajar dengan bermain anak tangga di depan kelas dan siswa lain memperhatikan. Dari siklus 1 ke siklus 2, siswa terlihat aktif melakukan kegiatan pembelajaran, guru semakin termotivasi untuk melaksanakan pembelajaran dengan metode bermain anak tangga.Pada kondisi akhir melalui metode bermain anak tangga pada materi pengukuran satuan panjang hasil belajar siswa meningkat. Untuk mengetahui peningkatan siswa dalam perbaikan pembelajaran diperlukan indikator.Indikator yang diperlukan untuk mengukur peningkatan pemahaman siswa adalah ketuntasan dalam pembelajaran.Siswa 
dikatakan tuntas belajar jika telah mencapai tingkat hasil belajar terhadap materi pengukuran satuan panjang adalah mencapai nilai 60 (sesuai KKM) atau lebih.

\section{HASIL DAN PEMBAHASAN}

\section{Siklus 1}

Subjek penelitian adalah siswa kelas III SD Negeri 1 Karanganyar Kecamatan Jatilawang Kabupaten Banyumas pada semester II Tahun pelajaran 2015/2016 yang berjumlah 19 siswa terdiri dari 12 siswa anak laki-laki dan 9 siswa perempuan. Usia siswa rata-rata 8 tahun.

Tabel 1. PeningkatanMinat Belajar Siswa dalam Proses Pembelajaran Kondisi Awal dan Siklus I

\begin{tabular}{|c|c|c|c|c|c|c|c|c|c|}
\hline \multirow[b]{3}{*}{ No } & \multirow{3}{*}{$\begin{array}{l}\text { Nama } \\
\text { Siswa }\end{array}$} & \multicolumn{8}{|c|}{ Minat Belajar } \\
\hline & & \multicolumn{4}{|c|}{ Studi Awal } & \multicolumn{4}{|c|}{ Siklus I } \\
\hline & & $\mathrm{A}$ & B & $\mathrm{C}$ & $\begin{array}{l}\text { Jumlah } \\
\text { Indikator }\end{array}$ & $\mathrm{A}$ & $\mathrm{B}$ & $\mathrm{C}$ & $\begin{array}{l}\text { Jumlah } \\
\text { Indikator }\end{array}$ \\
\hline 1. & Daniswara & $\sqrt{ }$ & & & 1 & $\sqrt{ }$ & & & 1 \\
\hline 2. & Putri A & & & $\sqrt{ }$ & 1 & $\sqrt{ }$ & & $\sqrt{ }$ & 2 \\
\hline 3. & Nafisa A & $\sqrt{ }$ & $\sqrt{ }$ & & 2 & $\sqrt{ }$ & $\sqrt{ }$ & & 2 \\
\hline 4. & Evan R & $\sqrt{ }$ & $\sqrt{ }$ & & 2 & $\sqrt{ }$ & $\sqrt{ }$ & $\sqrt{ }$ & 3 \\
\hline 5. & Frendi Arivin & $\sqrt{ }$ & & & 1 & $\sqrt{ }$ & $\sqrt{ }$ & & 2 \\
\hline 6. & Fauzi H & $\sqrt{ }$ & & & 1 & $\sqrt{ }$ & $\sqrt{ }$ & & 2 \\
\hline 7. & Andra $\mathrm{N}$ & $\sqrt{ }$ & & $\sqrt{ }$ & 2 & $\sqrt{ }$ & $\sqrt{ }$ & $\sqrt{ }$ & 3 \\
\hline 8. & Fauzi H & $\sqrt{ }$ & $\sqrt{ }$ & & 2 & $\sqrt{ }$ & $\sqrt{ }$ & $\sqrt{ }$ & 3 \\
\hline 9. & Salasa N & & $\sqrt{ }$ & & 1 & & $\sqrt{ }$ & $\sqrt{ }$ & 2 \\
\hline 10. & Krisna & $\sqrt{ }$ & & $\sqrt{ }$ & 2 & $\sqrt{ }$ & $\sqrt{ }$ & $\sqrt{ }$ & 3 \\
\hline 11. & Kurnia & & $\sqrt{ }$ & & 1 & $\sqrt{ }$ & $\sqrt{ }$ & $\sqrt{ }$ & 3 \\
\hline 12. & Muhammad & $\sqrt{ }$ & & & 1 & $\sqrt{ }$ & & & 1 \\
\hline 13. & Muhammad AB & & & $\sqrt{ }$ & 1 & $\sqrt{ }$ & & $\sqrt{ }$ & 2 \\
\hline 14. & Najwa Safa $S$ & & & $\sqrt{ }$ & 1 & & & $\sqrt{ }$ & 1 \\
\hline 15. & Nikolas Maulana & $\sqrt{ }$ & & & 1 & $\sqrt{ }$ & $\sqrt{ }$ & $\sqrt{ }$ & 3 \\
\hline 16 & Ririn putriani & & $\sqrt{ }$ & & 1 & & $\sqrt{ }$ & & 1 \\
\hline 17 & Andika S & $\sqrt{ }$ & & & 1 & $\sqrt{ }$ & $\sqrt{ }$ & $\sqrt{ }$ & 3 \\
\hline 18 & Yuanita Damartuti & & $\sqrt{ }$ & & 1 & & $\sqrt{ }$ & $\sqrt{ }$ & 2 \\
\hline 19 & Fahmi A & $\sqrt{ }$ & & & 1 & $\sqrt{ }$ & & & 1 \\
\hline $\begin{array}{l}\text { Jum } \\
\text { min }\end{array}$ & $\begin{array}{l}\text { ah siswa yang menun } \\
\text { t belajar }\end{array}$ & ukk & & & 5 & & & & 14 \\
\hline Pers & ntase minat belajar & & & & $26 \%$ & & & & $73 \%$ \\
\hline
\end{tabular}

Keterangan :

Siswa dikatakan memiliki minat belajar jika menunjukkan minimal dua indikator.
A : Keaktifan
B : Antusias
C : Respon siswa terhadap penjelasan guru 
Hanya 4 siswa (21\%) yang sudah benar-benar memahami pengukuran satuan panjang. Hal tersebut terlihat dari keaktifan siswa saat tanya jawab tentang materi tersebut. Ada beberapa siswa yang mendokumentasikan materi dalam buku catatan. Ketika guru menjelaskan sebagian besar siswa mencatat aturan hubungan satuan panjang. Ada siswa yang berbicara dengan teman dan ada juga yang tidak kosentrasi. Ketika membentuk kelompok beranggotakan 4 siswa, ada beberapa siswa yang tidak mengikuti perintah guru untuk berkelompok dengan teman di depan/di belakangnya. Mereka lebih memilih teman yang mereka sukai. Kerja kelompok belum semua berjalan maksimal. Dalam beberapa kelompok ada anggota yang tidak mengerjakan tugas dari guru secara maksimal. Dengan demikian, secara keseluruhan, situasi atau suasana pembelajaran berjalan baik. Siswa aktif dalam merespon penyampaian materi dari guru. Hasil Belajar Ulangan pada siklus I diikuti oleh 19 siswa. Telah terjadi peningkatan pemahaman tentang pengukuran satuan panjang. Delapan (8) siswa (42\%) sudah dapat memahami hubungan antarsatuan panjang. Sementara masih ada sebelas (11) siswa ( 58\% ) yang masih kurang memahami hubungan antar satuan panjang. Berdasarkan hasil evaluasi siklus I diketahui bahwa siswa pada umumnya dapat memahami dan mengerti hubungan antarsatuan panjang, tetapi hasil akhirnya masih salah. Hanya ada delapan (8) siswa (42\%) yang benar dalam menentukan hasil akhirnya.Hasil Belajar siswa pada siklus I terlihat jelas pada Tabel 2.

Tabel 2. Analisis Hasil Nilai Ulangan dan Ketuntasan Hasil Belajar Siswa Siklus I

\begin{tabular}{|c|l|c|}
\hline No & \multicolumn{1}{|c|}{ Uraian } & Jumlah \\
\hline 1. & Nilai Tertinggi & 80 \\
2. & Nilai Terendah & 50 \\
3. & Nilai Rerata & 61 \\
4. & Rentang Nilai & 30 \\
5. & Siswa Tuntas Belajar & 8 \\
6. & Siswa Tidak Tuntas Belajar & 11 \\
\hline
\end{tabular}

\begin{tabular}{|l|l|c|c|c|c|c|c|}
\hline & \multirow{2}{*}{} & Studi Awal & Siklus I & \multicolumn{5}{|c|}{ Siklus II } \\
\cline { 3 - 8 } & $\begin{array}{c}\text { Jumlah } \\
\text { Indikator }\end{array}$ & $\begin{array}{c}\text { Jumlah } \\
\text { Indikator }\end{array}$ & A & B & C & Ket \\
\hline 1. & Daniswara & 1 & 1 & $\sqrt{ }$ & & $\sqrt{ }$ & 2 \\
2. & Putri A & 1 & 2 & $\sqrt{ }$ & $\sqrt{ }$ & $\sqrt{ }$ & 3 \\
3. & Nafisa A & 1 & 1 & $\sqrt{ }$ & & $\sqrt{ }$ & 2 \\
4. & Evan R & 2 & 3 & $\sqrt{ }$ & $\sqrt{ }$ & $\sqrt{ }$ & 3 \\
5. & Frendi Arivin & 1 & 2 & $\sqrt{ }$ & $\sqrt{ }$ & $\sqrt{ }$ & 3 \\
6. & Fauzi H & 1 & 2 & $\sqrt{ }$ & $\sqrt{ }$ & $\sqrt{ }$ & 3 \\
7. & Andra N & 2 & 3 & $\sqrt{ }$ & $\sqrt{ }$ & $\sqrt{ }$ & 3 \\
8. & Fauzi H & 2 & 3 & $\sqrt{ }$ & $\sqrt{ }$ & $\sqrt{ }$ & 3 \\
\hline
\end{tabular}




\begin{tabular}{|c|c|c|c|c|c|c|}
\hline 9. Salasa N & 1 & 2 & $\sqrt{ }$ & $\sqrt{ }$ & $\sqrt{ }$ & 3 \\
\hline 10. Krisna & 2 & 3 & $\sqrt{ }$ & $\sqrt{ }$ & $\sqrt{ }$ & 3 \\
\hline 11. Kurnia & 1 & 3 & $\sqrt{ }$ & $\sqrt{ }$ & $\sqrt{ }$ & 3 \\
\hline 12. Muhammad & 1 & 1 & $\sqrt{ }$ & $\sqrt{ }$ & $\sqrt{ }$ & 3 \\
\hline $\begin{array}{l}\text { 13. Muhammad } \\
\mathrm{AB}\end{array}$ & 1 & 2 & $\sqrt{ }$ & & $\sqrt{ }$ & 2 \\
\hline 14. Najwa Safa $S$ & 1 & 1 & $\sqrt{ }$ & $\sqrt{ }$ & & 2 \\
\hline $\begin{array}{l}\text { 15. Nikolas } \\
\text { Maulana }\end{array}$ & 1 & 1 & $\sqrt{ }$ & & $\sqrt{ }$ & 2 \\
\hline 16 Ririn putriani & 1 & 1 & $\sqrt{ }$ & $\sqrt{ }$ & $\sqrt{ }$ & 3 \\
\hline 17 Andika S & 2 & 3 & $\sqrt{ }$ & $\sqrt{ }$ & $\sqrt{ }$ & 3 \\
\hline $18 \begin{array}{l}\text { Yuanita } \\
\text { Damartuti }\end{array}$ & 1 & 1 & $\sqrt{ }$ & & $\sqrt{ }$ & 2 \\
\hline 19 Fahmi A & 1 & 1 & $\sqrt{ }$ & $\sqrt{ }$ & $\sqrt{ }$ & 3 \\
\hline $\begin{array}{l}\text { Jumlah siswa yang } \\
\text { menunjukkan } \\
\text { minat belajar }\end{array}$ & 5 & 11 & & & & 18 \\
\hline $\begin{array}{l}\text { Persentase minat } \\
\text { belajar }\end{array}$ & $30 \%$ & $58 \%$ & & & & $100 \%$ \\
\hline
\end{tabular}

Keterangan :

Siswa dikatakan memiliki minat belajar jika menunjukkan minimal dua indikator.
A : Keaktifan
B : Antusias
C : Respon siswa terhadap penjelasan guru

Deskripsi Jurnal Guru Kolaborasi ulangan pada siklus II diikuti oleh 19 siswa. Nilai tertinggi siswa 90, nilai terendah 50, nilai rerata 72,5 dan rentang nilai 40. Dari 19 siswa 18 siswa dinyatakan tuntas belajar (95\%) sedangakan 1 siswa belum tuntas belajar (5\%). Berdasarkan hasil evaluasi siklus I diketahui bahwa siswa pada umumnya dapat memahami dan mengerti pengerjaan pengukuran satuan panjang, tetapi masih ada 1 siswa yang hasil akhirnya masih salah. Sedangkan 18 siswa (95\%) telah mengerjakan dengan benar. Hasil Belajar siswa pada siklus II terlihat jelas pada Tabel 3.

Tabel 3. Hasil Analisis Nilai Ulangan dan Ketuntasan Belajar Siklus II

\begin{tabular}{l|l|c|}
\hline No & \multicolumn{1}{|c|}{ Uraian } & Jumlah \\
\hline 1. & Nilai Tertinggi & 90 \\
2. & Nilai Terendah & 50 \\
3. & Nilai Rerata & 72,5 \\
4. & Rentang Nilai & 40 \\
5. & Siswa Tuntas Belajar & 18 \\
6. & Siswa Belum Tuntas Belajar & 1 \\
\hline \multicolumn{2}{|c|}{ Dari Tabel 3 dapat diketahui nilai yang telah diperoleh siswa dalam proses } \\
pembelajaran siklus II yaitu nilai tertinggi 90, nilai terendah 50, nilai rerata 72,5 dan \\
rentang nilai 40. Perbandingan terlihat lebih nilai tertinggi, terendah, rerata, rerata dan \\
rentang nilai pada siklus II jelas dalam Gambar 2 \\
\hline
\end{tabular}




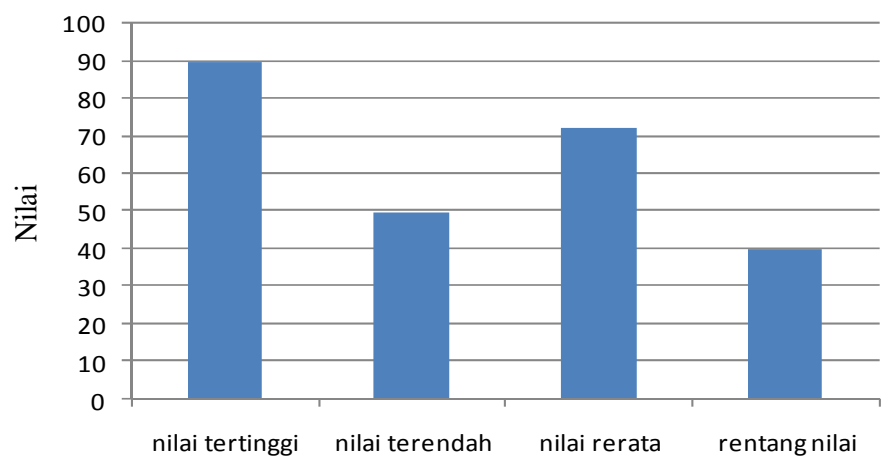

Gambar 2. Grafik Nilai Tertinggi, Nilai Terendah, Nilai Rerata, rentang Nilai Ulangan Siklus II

Tabel 4.Perbandingan Nilai dan Ketuntasan Belajar Siswa Kondisi Awal dengan Nilai Siklus I dan Siklus II

\begin{tabular}{|c|c|c|c|c|}
\hline No & Uraian & Kondisi Awal & Siklus I & Siklus II \\
\hline 1. & Nilai Tertinggi & 70 & 80 & 90 \\
\hline 2. & Nilai Terendah & 40 & 50 & 50 \\
\hline 3. & Nilai Rerata & 53 & 61 & 75,52 \\
\hline 4. & Rentang Nilai & 30 & 30 & 40 \\
\hline 5. & Siswa Tuntas & 4 & 8 & 18 \\
\hline 6. & Siswa Belum Tuntas & 15 & 11 & 1 \\
\hline
\end{tabular}
sebanyak 5 siswa (26\%). Setelah dilaksanakan tindakan perbaikan pada siklus I siswa yang menunjukkan minat belajar menjadi 11 siswa (57\%). Jadi ada peningkatan minat belajar sebesar $31 \%$. Perhatian siswa belum terlihat karena masih banyak dari mereka yang acuh tak acuh terhadap pelajaran yang sedang disampaikan. Berdasarkan pengamatan, rasa ingin tahu siswa dalam pembelajaran belum banyak yang muncul, dan motivasi mereka terasa masih sangat kurang. Hal tersebut mungkin disebabkan karena metode pembelajaran yang digunakan belum tepat sasaran. Pada studi awal siswa yang tuntas belajar sebanyak 4 siswa (21\%), yang belum tuntas ada 15 siswa (79\%) dengan nilai rata-rata kelas 53. Setelah dilakukan perbaikan pembelajaran pada siklus I, jumlah siswa yang tuntas belajar menjadi 8 siswa (42\%), yang belum tuntas sebanyak 11 siswa (58\%) dengan nilai rata-rata kelas 61. Jadi ada peningkatan ketuntasan belajar sebesar 16\%, dan kenaikan nilai rata-rata kelas sebesar 8 dari studi. Pada Siklus II jumlah siswa yang menunjukkan minat belajar menjadi 18 siswa (95\%). Jadi ada peningkatan sebesar 53\% dari siklus I. Peningkatan tesebut disebabkan karena perhatian, rasa ingin tahu, dan motivasi siswa juga meningkat. Dengan diterapkannya metode pembelajaran dengan memaksimalkan metode bermain anak tangga maka peneliti dapat lebih besar perhatiannya terhadap masing-masing siswa dalam mengikuti pembelajaran.Secara psikologis siswa menjadi lebih besar pula minatnya 
terhadap pembelajaran yang sedang berlangsung sehingga mereka merasa harus bisa berfikir kritis sebab pembelajaran yang sedang berlangsung merupakan pembelajaran menyelesaikan masalah secara kerja kelompok kecil. Pada siklus II ini jumlah siswa yang tuntas belajar sudah mencapai 18 siswa (95\%) yang belum tuntas hanya 1 siswa (5\%) dengan nilai rata-rata kelas mencapai 72,5. Jadi ada peningkatan ketuntasan belajar sebesar 53\%, dan nilai rata-rata kelas sebesar 11,5 dari siklus I. Berarti perbaikan pembelajaran sudah berhasil dan melebihi kriteria keberhasilan yang telah ditentukan yaitu $85 \%$ siswa tuntas belajar sehingga upaya perbaikan berakhir pada siklus kedua walaupun masih ada 1 siswa yang belum tuntas belajar.

\section{KESIMPULAN}

Adanya peningkatan minat belajar siswa dari studi awal ke siklus pertama dan siklus pertama ke siklus kedua yaitu pada kondisi awal minat siswa sebesar 26\%,siklus pertama minat siswa sebesar $57 \%$, dan pada siklus kedua minat siswa sebesar $100 \%$. Adanya peningkatan kemampuan hasil belajar matematika siswa yang ditunjukkan dengan peningkatan hasil tes matematika siswa dan ketuntasan belajar siswa kondisi awal ke siklus pertama dan siklus kedua. Pada Kondisi awal diperoleh nilai rata-rata hasil belajar matematika siswa sebesar 53 dengan ketuntasan belajar 21\%, siklus pertama diperoleh nilai rata-rata hasil belajar matematika siswa sebesar 61 dengan ketuntasan belajar $42 \%$ dan pada siklus kedua diperoleh nilai rata-arat hasil belajar matematika sebesar 72,5 dengan ketuntasan belajar $95 \%$.

\section{SARAN}

Perlu dikembangkan berbagai model jigsaw bervariasi untuk menciptakan berbagai model pembelajaran inovatif

\section{DAFTAR PUSTAKA}

Abdurrahman, M. (2003). Pendidikan Bagi Anak Berkesulitan Belajar. Jakarta: Rineka Cipta.

Armaini. (2004). Matematika 6 untuk Sekolah Dasar Kelas 6. Bandung: Acaraya Media Utama.

Daryanto. (1997). Materi Pokok Pengajaran Matematika. Jakarta: Karunia.

Dimyati dan Mujiono.(2006). Belajar dan Pembelajaran. Jakarta: Rineka Cipta. 
Gagne, R.dan Briggs, L. (1979). Principles of Instructional Design.Holt. Rinehart and Winston.

Handayani, W. (2011). Laporan Perbaikan Pembelajaran Melalui Penelitian Tindakan Kelas

Mata Pelajaran Matematika dan IPS di Kelas IV SD Negeri 1 Sitiadi Semester 1 Tahun Pelajaran 2011/2012. Purwokerto: UPBBJ Purwokerto

Hilgard, E. (1948). Theories of Learning. East Norwalk, CT, US: Appleton-CenturyCrofts.

Karso. (2002). Pendidikan Matematika 1. Jakarta: Universitas Terbuka.

Khafid, M. Dan Suyati. (2004). Pelajaran Matematika Penekanan Pada Berhitung Untuk Sekolah Dasar Kelas 6. Jakarta: Penerbit Erlangga.

Muhsetyo,G.(2008). Pembelajaran Matematika SD. Jakarata: Universitas Terbuka.

Purwadarminta.(1994). Kamus Umum Bahasa Indonesia. Jakarta: Balai Pustaka.

Purwanto, M. (1997). Psikologis Pendidikan. Bandung: PT Rosda Karya. 